\title{
The transfer of Eulophia beravensis Rchb. f. to Oeceoclades Lindl., a genus with its centre of diversity in Madagascar (Eulophiinae, Orchidaceae)
}

\author{
Ruth E. Bone, Ernesto Sanz \& Sven Buerki
}

\begin{abstract}
BONE, R. E., E. SANZ \& S. BUERKI (2014). The transfer of Eulophia beravensis Rchb. f. to Oeceoclades Lindl., a genus with its centre of diversity in Madagascar (Eulophiinae, Orchidaceae). Candollea 69: 201-205. In English, English and French abstracts.

Recent phylogenetic inferences among Eulophiinae genera have resolved Eulophia beravensis Rchb. f. as nested within the near-endemic Malagasy genus Oeceoclades Lindl. This result is supported by several morphological characters found in Eulophia beravensis that are diagnostic for Oeceoclades, and we therefore propose here to transfer this species to Oeceoclades. A species distribution map and a preliminary conservation assessment are also provided.
\end{abstract}

\section{Key-words}

ORCHIDACEAE - EULOPHIINAE - Oeceoclades - Eulophia - Madagascar

\section{Résumé}

BONE, R. E., E. SANZ \& S. BUERKI (2014). Le transfert d'Eulophia beravensis Rchb. f. à Oeceoclades Lindl., un genre avec son centre de diversité à Madagascar (Eulophiinae, Orchidaceae). Candollea 69: 201-205. En anglais, résumé français et anglais.

De récentes études phylogénétiques incluant tous les genres d'Eulophiinae ont montré l'appartenance d'Eulophia beravensis Rchb. f. au genre Oeceoclades Lindl. Ce résultat est également confirmé par la présence de caractères morphologiques diagnostique du genre Oeceoclades chez Eulophia beravensis. Sur la base de ces évidences, nous proposons ici le transfert d'Eulophia beravensis dans Oeceoclades. Une carte de distribution ainsi qu'une évaluation du statut de conservation de cette espèce sont aussi présentées.

Address of the authors: Royal Botanic Gardens, Kew, Richmond, Surrey, TW9 3AB, U.K.

E-mail (REB): r.bone@kew.org 


\section{Introduction}

Oeceoclades Lindl. is a genus of terrestrial orchids that has a centre of diversity in Madagascar (67\% of the 39 species; WCSP, 2014) where many species are restricted to dry forests and most are narrow endemics (Bosser \& LeCOUfLe, 2011; CRIBB \& HeRmans, 2009). The remaining species of the genus are endemic to other Western Indian Ocean islands (Réunion, the Seychelles, and the Zanzibar Archipelago) or have an AfroMalagasy distribution (Madagascar and the Comoros islands, and Tanzania to Mozambique), while a few are widespread in central Africa and two species, Oeceoclades maculata (Lindl.) Lindl. and $O$. pulchra (Thouars) Lindl., are almost pantropical (WCSP, 2014).

Oeceoclades was reinstated by GARAY \& TAYLOR (1976), however, few morphological characters can be used to consistently distinguish it from the much more speciose and widespread genus Eulophia R. Br., a terrestrial genus with a centre of diversity in Africa (CRIBB, 1987). The presence of two fleshy keels on the basal section of the lip (the hypochile) in Oeceoclades (SUMMERHAYES, 1957; BOSSER \& MORAT, 2001), and the absence of these keels at this position in Eulophia appears to be the only diagnostic character that, to our knowledge, does not show intermediate forms in both genera. Until recently, the unpublished study cited in PRIDGEON \& al. (2009) was the only available molecular phylogenetic analysis to include Eulophia beravensis Rchb. f. It revealed a paraphyletic Oeceoclades due to the nested position of a sample of Eulophia beravensis within this genus, suggesting that either Oeceoclades should be treated as part of Eulophia, or that E. beravensis should be transferred to Oeceoclades. However, this study included few species and was based on a single plastid DNA region ( $m a t K$; PRIDGEON \& al., 2009). A recent molecular phylogeny conducted by the authors, based on an extensive sampling of Oeceoclades and representatives of all Eulophiinae genera, recovered a similar phylogenetic position for E. beravensis, within the monophyletic Oeceoclades (Fig. 1).

The phylogenetic position of Eulophia beravensis is not unexpected. This Malagasy endemic, which was previously included in the genus Lissochilus R. Br. (as Lissochilus beravensis (Rchb. f.) H. Perrier), displays the diagnostic floral character of Oeceoclades, as described above. In addition, this species occurs in dry-forest and shrub-grassland habitats on sandy soils, which are ecologically more typical for the genus Oeceoclades than for Eulophia (which are more commonly found in dry and seasonally inundated grasslands; Williamson, 1977; la Croix \& CRIBB, 1998). Garay \& TAYLOR (1976) regarded the coriaceous conduplicate leaf character, such as is found in E. beravensis, as diagnostic for Oeceoclades, but appear to have overlooked Eulophia beravensis when they transferred other Malagasy Lissochilus to this genus.
Here we propose the transfer of Eulophia beravensis to the genus Oeceoclades. In addition, we provide a distribution map and a preliminary conservation assessment based on IUCN Red List Categories and Criteria (IUCN, 2012).

\section{Taxonomy}

Oeceoclades beravensis (Rchb. f.) R. Bone \& Buerki, comb. nova.

$\equiv$ Eulophia beravensis Rchb. f. in Bot. Zeitung (Berlin): 39: 449. 1881.

$\equiv$ Graphorkis beravensis (Rchb. f.) Kuntze, Revis. Gen. P1. 2: 662. 1891.

$\equiv$ Lissochilus beravensis (Rchb. f.) H. Perrier in Humbert, Fl. Madagascar Comores 49(2): 42. 1941.

Typus: Madagascar. Prov. Mahajanga: Beravi, VII. 1879, Hildebrandt 3055 (holo-: W [W-Rchb.Orch.0010 984] image seen; iso-: BM [BM000525715]!, GOET [GOET008578] image seen, K [K000410344]!; M [M0103 484] image seen, P [P000108 614]!).

Habitat and Ecology. - Oeceoclades beravensis has a broad distribution in the sub-humid to sub-arid areas of Madagascar to the west and south, where it grows in sandy soils, often forming dense stands in the understorey of western dry forest and wooded grassland-bushland mosaic (sensu MOAT \& SMITH, 2007) (Fig. 2).

Conservation status. - Oeceoclades beravensis is currently considered to be endemic to Madagascar, where it is widespread. The vegetation types that it occupies are threatened, however. The wooded grassland-bushland mosaic, generally considered to be a secondary vegetation type (MOAT \& SMITH, 2007; although see BOND \& al., 2008 for alternative views on grassland origins) is disturbed by cattle grazing, clearance for fuelwood and human mediated fires (MоAT \& SMITH, 2007). The western dry forest is targeted for charcoal and fuelwood and, according to MOAT AND SMITH (2007), is being cleared at a faster rate than any other forest type in Madagascar. Based on 40 collections from several herbaria (BM, K, MO and P; acronyms follow THIERS, 2014) an "Extent of Occurrence" of $397,139 \mathrm{~km}^{2}$, an "Area of Occupancy" (AOO) of $360 \mathrm{~km}^{2}$ and 39 subpopulations (calculation following CALLMANDER \& al., 2007), including six in the Protected Area network (Andranomena, Ankarafantsika, Ankarana, Baie de Baly, Namoroka, and Zombisty), O. beravensis is assigned a preliminary status of "Near Threatened" [NT] following IUCN Red List Categories and Criteria (IUCN, 2012). Under the "B" Criteria, based solely on EOO, this species would be categorized as "Least Concern", however it occurs in vegetation that is threatened by land use change (see above) and we adopt a precautionary approach as recommended by the Red List Guidelines (IUCN, 2014). The specimens used for the assessment are included on the "Eulophiinae Scratchpad" (Bone, 2014). 


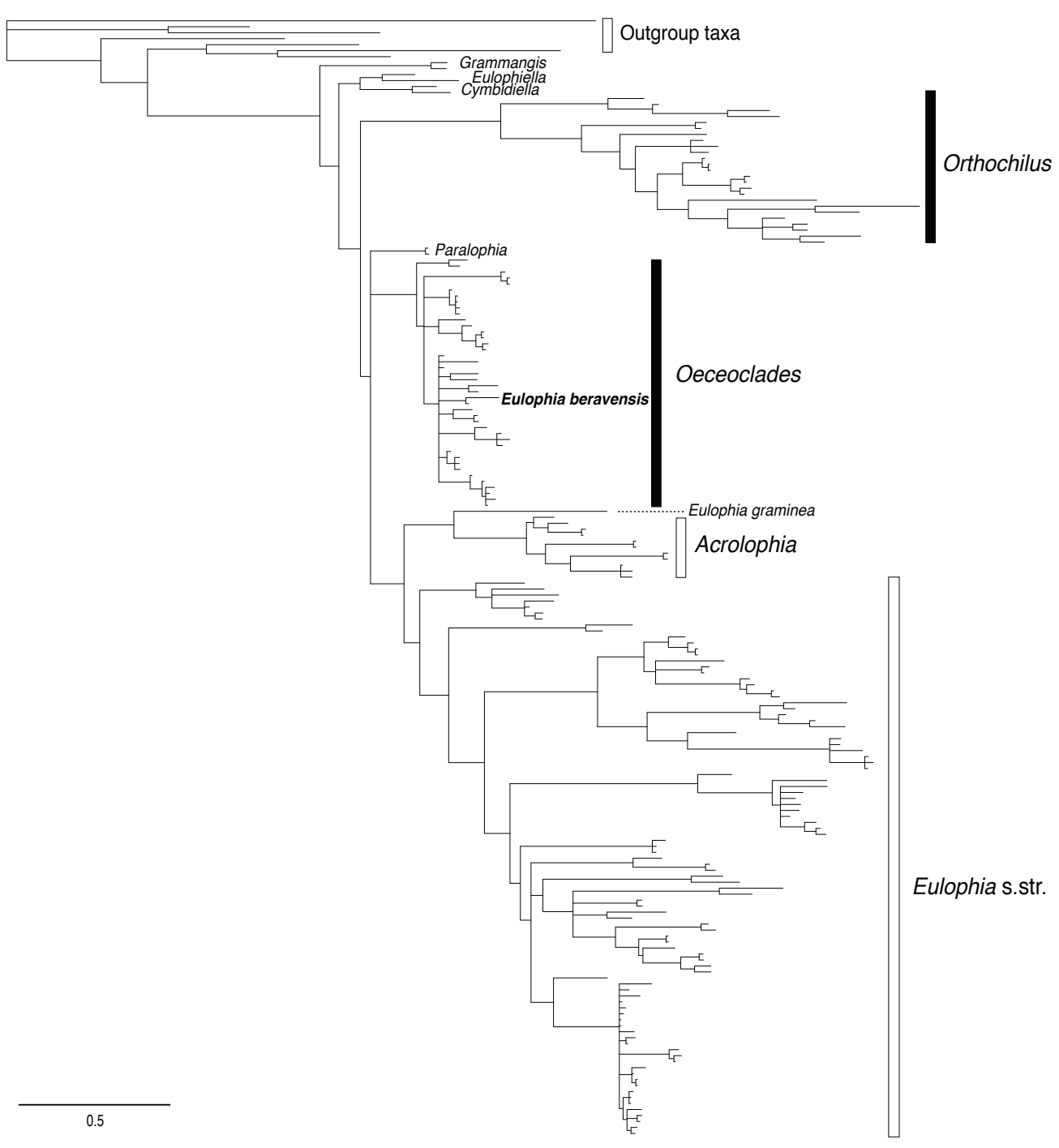

Fig. 1. - Simplified Bayesian plastid phylogeny of the tribe Eulophiinae showing Eulophia beravensis (Rchb. f.) R. Bone \& Buerki nested within species of Oeceoclades Lindl.

Observations. - Eulophia beravensis is morphologically unique among all Malagasy Eulophiinae taxa, including Oeceoclades, by having cane like stems that form large clumps or dense stands in scrub and forest understorey. Like the xerophytic Eulophia species E. leachii A. V. Hall (from Southern Africa) and E. petersii (Rchb. f.) Rchb. f. (a widespread species across dryland Africa and extending into the Arabian Peninsula; WCSP, 2014) the leaves of $E$. beravensis have minutely serrate margins (Fig. 3). They are, however, narrow and coriaceous, unlike these Eulophia species, that have somewhat fleshy almost succulent leaves. These morphological traits (that appear to be adaptations to arid and sub-arid environments) are clearly shown to have evolved independently based on unpublished molecular data produced by the authors, with all three taxa belonging to separate lineages.

The affinity of a species of Eulophia from Mozambique (E. biloba Schltr.), that was not sampled by the authors, should be investigated to determine whether it is conspecific with Oeceoclades beravensis (P. J. CRIBB, pers. comm.). If this is found to be the case, the validity of our comb. novae would be maintained since it bears the older basionym. The conservation assessment would require revision, however, to take into account a broader geographical distribution that would encompass Mozambique. 


\section{Acknowledgements}

We are grateful to the Swiss Orchid Foundation for funding this research and to the Editors of the Madagascar Notes at Candollea for their support and comments. Thanks also to Johan Hermans for contributing the image for Figure 3. We are grateful to Martin Callmander for advice on the preliminary conservation assessment.

\section{References}

Bond, W. J., J. A. Silander JR, J. Ranaivonasy \& J. Ratsirarson (2008). The antiquity of Madagascar's grasslands and the rise of C4 grassy biomes. J. Biogeog. 35: 1743-1758.

Bone, R. E. (2014). eMonocot Eulophiinae [http://eulophiinae.e-monocot.org].

Bosser, J. \& M. LeCoufle (2011). Les orchidées de Madagascar. Biotope, Mèze.

Bosser, J. \& P. Morat (2001). Contribution à l'étude des Orchidaceae de Madagascar \& des Mascareignes. XXXI. Espèces \& combinaisons nouvelles dans les genres Oeceoclades, Eulophia \& Eulophiella. Adansonia ser. 3, 23: 7-22.

Callmander, M. W., G. E. Schatz, P. P. Lowry II, M. O. Laivao, J. RAHARIMAMPIONONA, S. ANDRIAMBOLOLONERA, T. RAMINOSOA \& T. Consiglio (2007). Application of IUCN Red List criteria and assessment of Priority Areas for Plant Conservation in Madagascar: rare and threatened Pandanaceae indicate sites in need of protection. Oryx 41 : 168-176.

CORnEt, A. (1974). Essai de cartographie bioclimatique à Madagascar. Notice Explicative $n^{\circ}$ 55. ORSTOM, Paris.

CribB, P. J. (1987). The genus Eulophia in Africa. In: SAITO, K. \& R. TAnaka (ed.), Proceedings of the World Orchid Hiroshima Symposium: 97-103. Executive Committee of the World Orchid Hiroshima Symposium, Hiroshima.

CribB, P. J. \& J. Hermans (2009). Field guide to the orchids of Madagascar. Kew Publishing.

Garay, L. A. \& P. TAYLOR (1976). The genus Oeceoclades Lindl. Bot. Mus. Leafl. 24: 249-274.

IUCN (2012). IUCN Red List Categories and Criteria: Version 3.1. $2^{\text {nd }}$ Edition. IUCN Species Survival Commission, Gland \& Cambridge.

IUCN (2014). Guidelines for using the IUCN Red List Categories and Criteria. Version 11. IUCN, Standards and Petitions Subcommittee

[http://www.iucnredlist.org/documents/RedListGuidelines.pdf].

LA Croix, I. \& P. J. CRIBB (1998). Orchidaceae. In: Pope, G. V. (ed.), Fl. Zambesiaca. Kew Publishing.

Mont, J. \& P. Sмith (ed) (2007). Atlas of the vegetation of Madagascar. Royal Botanic Gardens, Kew.

Pridgeon, A. M., P. J. CribB, M. Chase \& F. Rasmussen (ed.) (2009). Genera Orchidacearum. Epidendroideae (Part two). Oxford University Press.
Schatz, G. E. (2000). Endemism in the Malagasy tree flora. In: Lourenço, W. R. \& S. Goodman, S. M. (ed.), Diversity and endemism in Madagascar: 1-9. Mémoires de la Société de Biogéographie. Paris.

Summerhayes, V. (1957). The genus Eulophidium Pfitz. Bull. Jard. Bot. Etat Bruxelles 27: 391-403.

THIERs, B. (2014). Index Herbariorum: A global directory of public herbaria and associated staff. New York Botanical Garden's Virtual Herbarium [http://sweetgum.nybg.org/ih].

WCSP (2014). World Checklist of Selected Plant Families. Facilitated by the Royal Botanic Gardens, Kew [http://apps.kew.org/wcsp].

Williamson, G. (1977). The Orchids of South Central Africa. J. M. Dent \& Sons, Ltd., London.

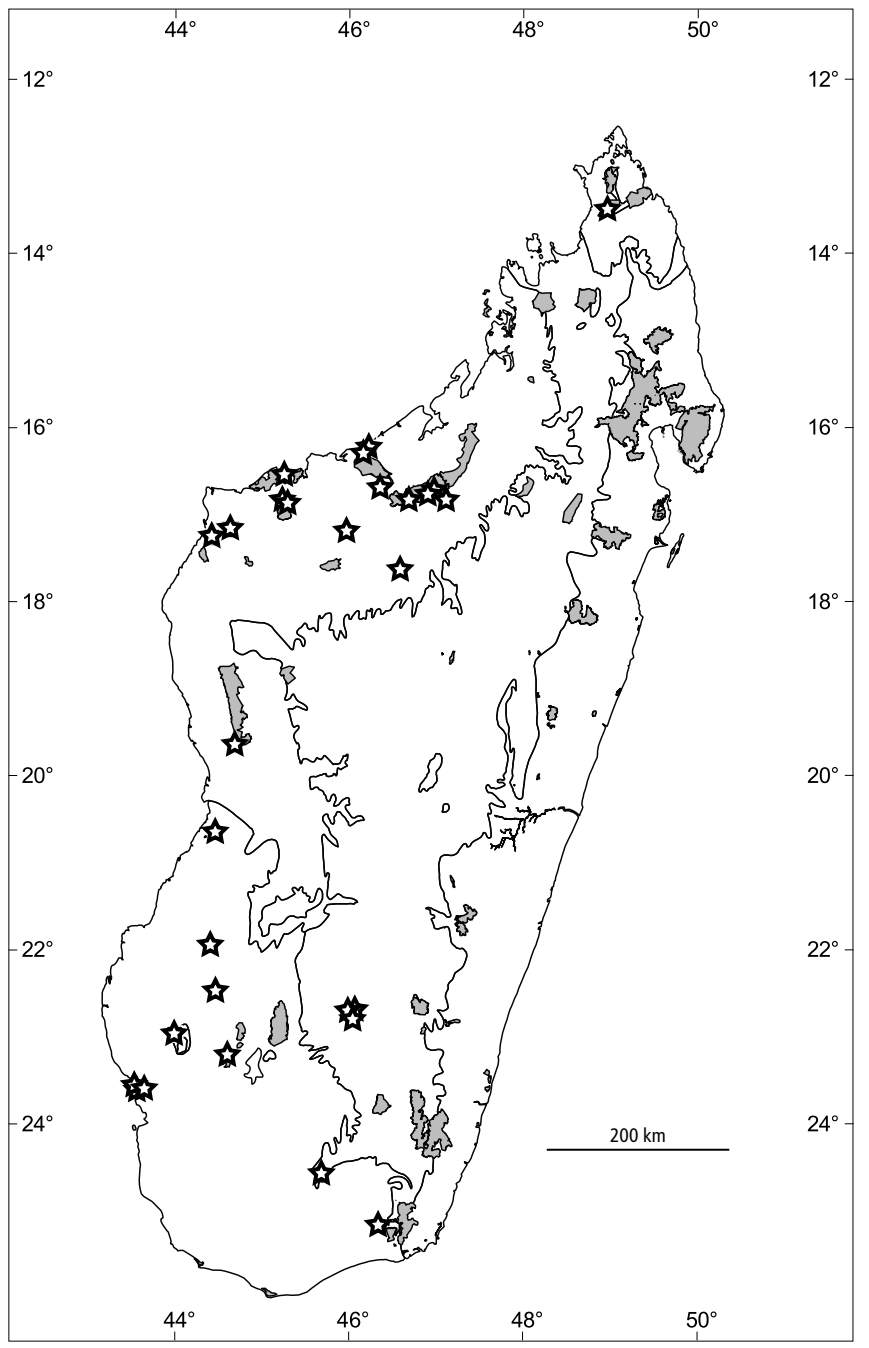

Fig. 2. - Distribution map of Oeceoclades beravensis (Rchb. f.) R. Bone \& Buerki (stars), based on herbarium specimens mapped on the bioclimatic zones of Madagascar (after CORNET, 1974; see SCHATZ, 2000). Protected areas are highlighted in grey. 


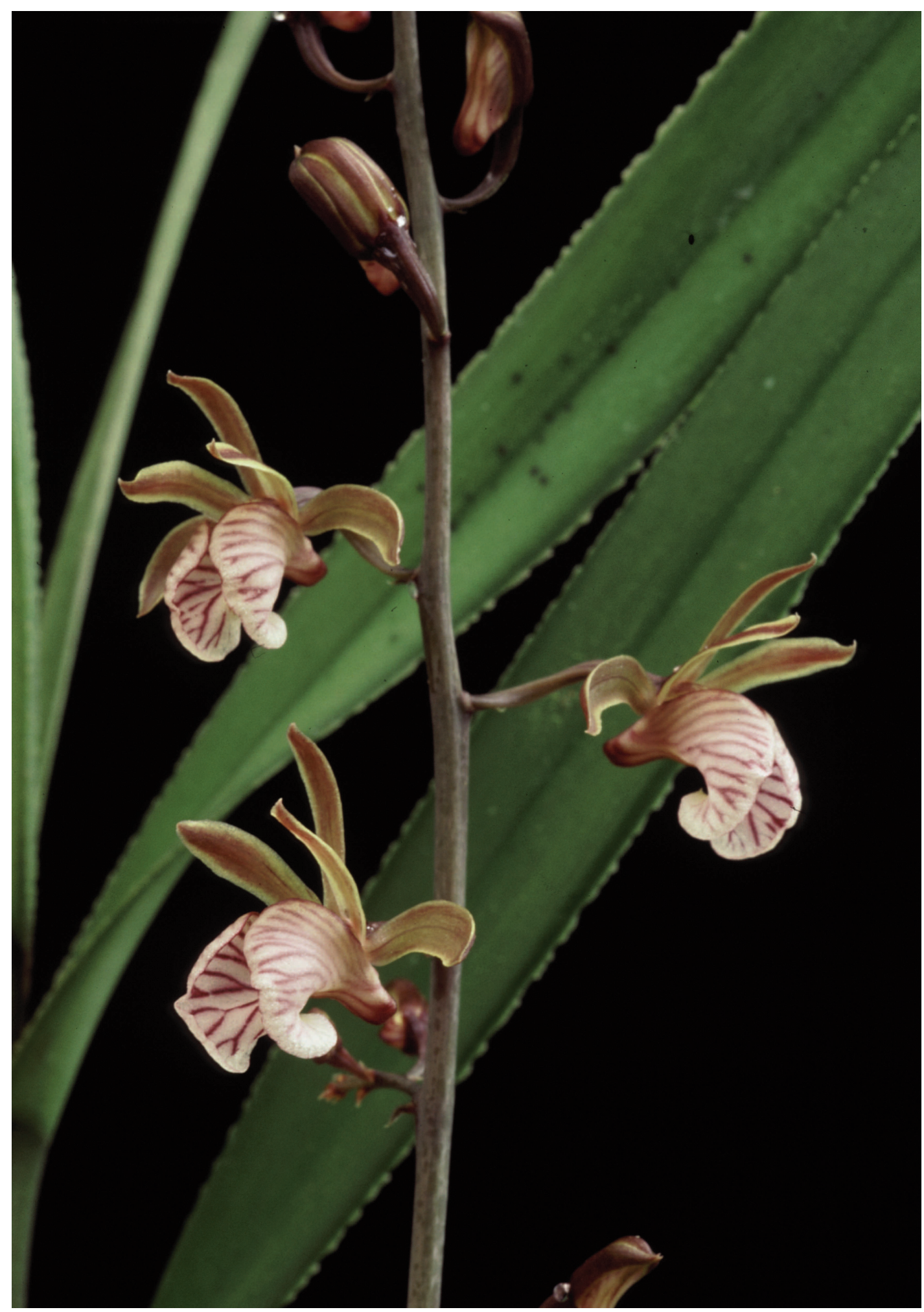

Fig. 3. - Oeceoclades beravensis (Rchb. f.) R. Bone \& Buerki (near Ihosy airport, Fianarantsoa Prov. in 1996). [Photo: J. Hermans] 